\title{
Teachers' aggressive and violent behaviours towards students with mild intellectual disabilities in three forms of education
}

\begin{abstract}
Marzena Buchnat, Teachers' aggressive and violent behaviours towards students with mild intellectual disabilities in three forms of education. Interdisciplinary Contexts of Special Pedagogy, no. 29, Poznań 2020. Pp. 97-115. Adam Mickiewicz University Press. ISSN 2300-391X. e-ISSN 2658-283X. DOI: https://doi.org/10. 14746/ikps.2020.29.05
\end{abstract}

Aggression and violence has become a regular part of school reality. The ongoing legal changes in the education system have provided children with mild intellectual disabilities the opportunity to study in three forms of education: mainstream schools, integration classes and special schools. Unfortunately, the results of many studies have revealed that students with disabilities are more likely to be subject to peer victimization, particularly in various forms of inclusive education. In view of such facts, the question arises whether, and if so, how and with what frequency students with mild intellectual disabilities in various forms of education experience aggression and violence perpetrated by teachers. This seems particularly important because of the role that teachers play in building a sense of security in students, especially those with mild intellectual disabilities. The results of the study revealed a much higher level of aggression and violence experienced by students with mild intellectual disabilities perpetrated by teachers working in mainstream schools compared to those working in special schools. This fact raises great reservations regarding the teachers' attitude towards students with mild intellectual disabilities and the level of their preparation for effective work with such students.

KEY WORDS: aggression and violence, teacher, school, student with mild intellectual disabilities 


\section{Introduction}

School is one of the most important social spaces where children and young people experience aggression and violence. The negative impact of experiencing such behaviours on the development of every person has made school aggression and violence one of the most pressing contemporary educational problems. Many variables influence the risk of becoming a victim of school aggression and violence. On the one hand, individual factors concerning the students themselves, such as their gender, age, character traits or their family homes play an important role, which is confirmed by numerous Polish and international studies. ${ }^{1}$ On the other hand, environmental factors, which are closely linked to the characteristics of the school, are also of great importance.

In the case of the causes of school aggression and violence, teachers play a special role, as they should prevent these behaviours from happening. Unfortunately, sometimes they not only do not fulfil their duty to prevent such behaviours, but also become perpetrators themselves, which leads to far-reaching negative consequences for the functioning of the student. The worst situation is faced by students who expect support from the teacher, for example due to peer victimisation due to their disability. In such a situation, the teacher, as the person who should help to instil a sense of security in the student, destroys it even further.

\section{Causes of school aggression and violence}

The causes of school aggression and violence can stem from a number of factors, the sources of which can be divided into three

${ }^{1}$ Cf. D. Schwartz, K.A. Dodge, \& J.D. Coie, “The emergence of chronic peer victimization in boys' play groups", Child Development, 1993, 64(6), 1755-1772; A. Komendant-Brodowska, A. Baczko-Dombi, A. Giza-Poleszczuk, Przemoc w szkole. Raport z badań, 2011, www.szkolabezprzemocy.pl [retrieved on: 28.11.2019]; J. Przewłocka, Bezpieczeństwo uczniów i klimat społeczny w polskich szkołach. Raport z badań, Wydawnictwo Instytutu Badań Edukacyjnych, Warsaw 2015. 
basic groups: related to the school as an institution, improper relations between teachers and students, as well as improper relations between students themselves. ${ }^{2}$

The first key area is school as an institution, and at the same time a source of psychological, symbolic and structural violence. Its various elements which may lead to the incidence of aggressive and violent behaviour include school space, which is usually too small, the number of students and teachers, equipment, educational curricula taught at school, limited ability to meet the need for physical activity, noise, as well as a particular way of spending time, which significantly limits the independence of children and youth, as well as their ability to make choices, work overload, incorrect assessment process and anonymity of participants.

The second area, focused on the analysis of the relationship between students and teachers, issues concern primarily the lack of respect for the dignity of the students. This includes the way a teacher communicates with a student based on humiliating, ridiculing and mocking in front of other people, as well as intimidating and showing authority. This also concerns establishing relationships based only on requirements without positive reinforcement or rewarding, acknowledging the student's achievements, as well as being emotionally cold towards the students, solving conflicts between the faculty and students with force-based strategies or teaching pressure. In this area, we can mention both physical aggression, as well as other factors pertaining to the teaching process, which have a direct bearing on the relationship between students and teachers. These include, but are not limited to, requirements that are not in line with the capabilities and needs of individual students, unfair treatment and assessment of a student, failure to ensure the student's success, focusing on the difficulties and deficiencies of individual students, without appreciating their progress. This also includes Insufficient time devoted to the educational processes,

${ }^{2}$ J. Surzykiewicz, Agresja i przemoc w szkole. Uwarunkowania socjoekologiczne, Centrum Metodyczne Pomocy Psychologiczno-Pedagogicznej, Warsaw 2000. 
such as conflict resolution, reducing tension during classes, and so on. The incidence of school aggression and violence in the area of relations between students and teachers is also exacerbated by the lack of negation of such behaviours by other teachers, inconsistency of these reactions among teachers, lack of clear rules of school life, as well as inconsistency of teachers in enforcing the adopted standards.

The third factor concerns the abnormal relationships between the students themselves, which may stem from individual personal characteristics, in particular reduced self-control, high impulsivity, short attention span, attention deficits. Aggressive and violent behaviours can also be a consequence of students experiencing situations where, for example, they notice that a violent student benefits from their behaviour without losing their popularity, and without suffering any negative consequences of their behaviour. The perpetrator of violence is viewed positively by the social group as a brave person, while their committed acts of violence build their high social standing. The conviction that in the group the sense of responsibility is distributed and the sense of guilt is reduced forms yet another incentive to join the group of perpetrators. ${ }^{3}$

These days, the analysis of the phenomenon of school aggression and violence needs to also include the media, which play an increasingly important role in the upbringing of young people. Watching acts of violence has a quantifiable effect on children and youth, as it impacts them by teaching them aggressive behaviours, in particular in the cases where violence is presented in a realistic and attractive way, brings satisfaction to the perpetrator, is not punished or is justified by higher social reasons, or presented as socially acceptable.

${ }^{3}$ J. Surzykiewicz, Agresja i przemoc w szkole. Uwarunkowania socjoekologiczne, Centrum Metodyczne Pomocy Psychologiczno-Pedagogicznej, Warsaw 2000; K. Ostrowska, J. Surzykiewicz, Zachowania agresywne w szkole. Badania porównawcze 1997 i 2003, Centrum Metodyczne Pomocy Psychologiczno-Pedagogicznej, Warsaw 2005; G. Poraj, Szkoła wobec agresji, Psychologia w Szkole, 2006, no. 1 pp. 3-24; I. Pufal-Struzik (ed.), Agresja dzieci i młodzieży, Wydawnictwo Pedagogiczne ZNP, Kielce 2007. 


\section{The concept of school aggression and violence}

The analysis of the phenomenon of school aggression and violence requires the definition of the concepts, since the common knowledge of these concepts, especially at the intuitive level, makes it recognisable in everyday language; however, there are many ambiguities in their actual definitions. ${ }^{4}$ Aggression - from Latin word aggressio - means assault. The conducted study was based on the definition coined by Adam Frączek,, 5 which defines aggression as "acts aimed at doing harm and causing loss of socially-important values, inflicting physical pain or causing moral suffering to another person". The recognition of a given behaviour as aggressive hinges on three basic criteria - its intentional nature, its result - specific consequences of behaviour, as well as the moral and social context. ${ }^{6}$ In international literature, the authors usually quote the definition of violence coined by Dan Olweus, ${ }^{7}$ who defines violence/violent behaviour as aggressive behaviour where the actor or perpetrator uses his or her own body as an object (including a weapon) to inflict (relatively serious) injury or discomfort upon an individual, while this research project is based on Anna Brzezińska's definition of violence, ${ }^{8}$ which states

${ }^{4}$ M. Czub, Zachowanie agresywne - agresja - osiaganie. Analiza zjawiska agresji jako istotnego czynnika w procesie socjalizacji, Kwartalnik Pedagogiczny, 1992, no. 1, pp. 126-135.

${ }^{5}$ A. Frączek, Czynności agresywne jako przedmiot studiów eksperymentalnej psychologii społecznej, [in:] Studia nad psychologicznymi mechanizmami czynności agresywnych, (ed.) A. Frączek, Zakład Narodowy im. Ossolińskich - Wydawnictwo PAN, Wrocław-Warszawa-Kraków-Gdańsk 1979, p. 13.

${ }^{6}$ A. Frączek, Czynności agresywne jako przedmiot studiów eksperymentalnej psychologii społecznej, [in:] Studia nad psychologicznymi mechanizmami czynności agresywnych, Zakład Narodowy im. Ossolińskich - Wydawnictwo PAN, Wrocław-WarszawaKraków-Gdańsk 1979, p. 14; U. Meier, Aggressionen und Gewalt in der Schule. Zur Dialektik von Schülerpersönlichkeiten, Lernumwelten und schulischem Sozialklima. Jugendsoziologie, vol. 6, Münster 2004, p. 19.

7 D. Olweus, Mobbing. Fala przemocy w szkole. Jak ja powstrzymać?, Agencja Wydawnicza Jacek Santorski \& Co, Warsaw 2007.

${ }^{8}$ A. Brzezińska, Jak rodzi się agresja?, [in:] Dzieci i młodzież wobec agresji i przemocy, A. Brzezińska, E. Hornowska (eds.), Wydawnictwo Naukowe Scholar, Warsaw 2004, p. 108. 
that "violence is the abuse or use of one's physical, emotional or situational superiority over another individual to achieve an outcome deemed important by the perpetrator".

The ambiguity in consistently distinguishing the semantic field of the terms aggression and violence leads to methodological difficulties in researching these subjects. In this case, we see a phenomenon, which can be referred to as "conceptual diffusion" of these terms, which results in their mutual interpenetration and interchangeability; however, most current research on violence and aggression in the school setting adopt a combination of the two concepts, ${ }^{9}$ mostly due to the broadest possible coverage of different types of violent and aggressive behaviours of students and teachers alike. Due to the interchangeability of these concepts, as well as the subjectivity inherent in the assessment of certain forms of behaviour that can be interpreted as aggressive or violent, which are also determined by situational, cultural and social factors, it does not seem necessary to clearly define these two terms. The phenomenon of school aggression and violence has been defined by Marek Kulesza ${ }^{10}$ as "a broad range of deliberate acts and actions undertaken by members of the school community (...) which occur at school or on the way to school, and which result in physical or mental suffering of people on the school premises, as well as the destruction of property located on the school premises". On the basis of this definition and the analysis of these issues in the available sources, the author established that for the purpose of this study, the phenomenon of school aggression and violence is a broad spectrum of delib-

${ }^{9}$ A. Frączek, Agresja i przemoc wśród dzieci i młodzieży jako zjawisko społeczne, [in:] Agresja wśród dzieci i młodzieży. Perspektywa psychoedukacyjna, A. Frączek, I. Pufal-Struzik (eds.), Wydawnictwo Pedagogiczne ZNP, Kielce 1996; M. Kulesza, Klimat szkoty a zachowania agresywne i przemocowe uczniów, Wydawnictwo Uniwersytetu Łódzkiego, Łódź 2011; J. Surzykiewicz, Agresja i przemoc w szkole. Uwarunkowania socjoekologiczne, Centrum Metodyczne Pomocy Psychologiczno-Pedagogicznej, Warsaw 2000.

${ }^{10} \mathrm{M}$. Kulesza, Klimat szkoły a zachowania agresywne i przemocowe uczniów, Wydawnictwo Uniwersytetu Łódzkiego, Łódź 2011, p. 24. 
erate actions and acts undertaken by members of the school community, which occur at school or on the way to school, as well as over new communication technologies, and which result in physical or mental suffering of the members of this community, or destruction of property located on the school premises.

\section{Perpetrators of school violence and aggression}

The results of the conducted studies reveal that the most frequently experienced form of aggression and violence at school is peer violence, which can occur on the school premises, on the way to or from school, via a mobile phone or on the Internet. ${ }^{11}$

Peer violence, mainly physical violence, is more often perpetrated by boys than by girls, who, on the other hand, are more likely to engage in emotional violence. ${ }^{12}$ Not only do boys commit acts of physical violence more often than girls, but they are also more violent. ${ }^{13}$

The risk of becoming a victim of school aggression and violence hinges on a number of factors, including the individual characteristics and traits of the victim and the perpetrator, such as gender, social standing and more, as well as the social space, which can be conducive to such behaviours. ${ }^{14}$

${ }^{11}$ M. Kulesza, Klimat szkoły a zachowania agresywne i przemocowe uczniów, Wydawnictwo Uniwersytetu Łódzkiego, Łódź 2011; J. Włodarczyk, Przemoc rówieśnicza. Wyniki Ogólnopolskiej diagnozy problemu przemocy wobec dzieci, [in:] Dziecko krzywdzone. Teoria, badania, praktyka, 2013, 12(3), pp. 63-81; J. Włodarczyk, K. Makaruk, Ogólnopolska diagnoza problemu przemocy wobec dzieci. Wyniki badania, Fundacja Dzieci Niczyje, Warsaw 2013; A. Komendant-Brodowska, Agresja i przemoc szkolna. Raport o stanie badań, Wydawnictwo Instytutu Badań Edukacyjnych, Warsaw 2014.

12 M. Kulesza, Klimat szkoły a zachowania agresywne i przemocowe uczniów, Wydawnictwo Uniwersytetu Łódzkiego, Łódź 2011; J. Przewłocka, Bezpieczeństwo uczniów i klimat społeczny w polskich szkołach. Raport z badań, Wydawnictwo Instytutu Badań Edukacyjnych, Warsaw 2015; J. Pyżalski, Przemoc rówieśnicza w szkole - badania retrospektywne studentów pedagogiki, Studia Edukacyjne, 2015, no. 34, pp. 177-196.

13 I. Chmura-Rutkowska, Przemoc rówieśnicza w gimnazjum a płeć. Kontekst społeczno-kulturowy, Forum Oświatowe, 2012, no. 46(1), pp. 41-73.

14 Cf. D. Schwartz, K.A. Dodge, J.D. Coie, The emergence of chronic peer victimization in boys' play groups, Child Development, 1993, 64(6), pp. 1755-1772; A. Komen- 
The analysis of sources on aggression and violence of students with special needs, including students with disabilities shows that these students are more often subject to peer victimisation than their able-bodied counterparts. ${ }^{15}$ We may therefore conclude that disability is also one of the factors that determines the frequency of experiencing school aggression and violence.

Due to the fact that the source of school aggression and violence may include improper relationships between the students and teachers, in addition to peer relationships, it seems important to determine whether students with disabilities are also more likely to be victimised in this area.

Violent behaviour of teachers perpetrated against students have particularly negative outcomes when it comes to the occurrence of school aggression and violence, and above all for the development of children. The teacher should be an authority and a model of de-

dant-Brodowska, A. Baczko-Dombi, A. Giza-Poleszczuk (eds.), Przemoc w szkole. Raport $z$ badań, Warsaw 2011; szkolabezprzemocy.pl [retrieved on: 28.11.2019]; J. Przewłocka, Bezpieczeństwo uczniów i klimat społeczny w polskich szkołach. Raport $z$ badań, Wydawnictwo Instytutu Badań Edukacyjnych, Warsaw 2015.

${ }^{15} \mathrm{M}$. Buchnat, Percepcja klimatu szkoty przez uczniów z lekka niepetnosprawnościq intelektualna $w$ trzech formach ksztatcenia a agresja i przemoc szkolna, Wydawnictwo Naukowe UAM, Poznań 2019; E. Hodges, D. Perry, Personal and interpersonal antecedents and consequences of victimization by peers, Journal of Personality and Social Psychology, 1999, no. 76(4), pp. 677-685; A. Mikrut, Stygmat 'upośledzenie umystowe' a ryzyko zastania ofiara przemocy, Szkoła Specjalna, 2007, no. 3, pp. 184-191; W.J. Murphy, The victim advocacy and research group: Serving a growing need to provide rape victims with personal legal representation to protect privacy rights and to fight gender bias in the criminal justice", Journal of Social Distress and the Homeless, 2001, 10, pp. 123-138, D.G. Perry, S.J. Kusel, L.C. Perry (1998); Victims of peer aggression, Developmental Psychology, 1998, no. 24(6), pp. 807-814; D. Olweus, Mobbing. Fala przemocy $w$ szkole. Jak ja powstrzymać?, Agencja Wydawnicza Jacek Santorski \& Co, Warsaw 2007; P. Plichta, Dzieci i młodzież z niepetnosprawnościa intelektualna a narażenie na agresję rówieśnicza, [in:] Przemoc rówieśnicza wobec dzieci ze SPE. Materiały pokonferencyjne, Wydawnictwo Instytutu Badań Edukacyjnych, Warsaw 2015, pp. 35-42; I. Pospiszyl, Ofiary chroniczne. Przypadek czy konieczność, Wydawnictwo APS, Warsaw, 2003; Sveinsson A.V., Morris R.J., School bullying and victimization of children with disabilities, [in:] Disability Research and Policy: Current Perspectives, ed. R.J. Morris, Routlege, London 2005. 
sired social behaviours for the student, ${ }^{16}$ because by being the role model, they have an important impact on the process of bringing up children and youth at school. Unfortunately, as the results of the study show, 17 the position of authority allows teachers to use their power in working with children.

Such behaviours exhibited by teachers not only prevent students from getting help in situations of school aggression and violence, but also lead to the emergence of negative patterns of behaviour. They show students a way to deal with a specific situation, which they will use, unfortunately it is often a way based on aggression and violence. They are not only a role model that can be followed, but also create an atmosphere conducive to such forms of behaviour. Violent behaviour is particularly dangerous when it affects a selected group of children in the class or group, because they exacerbate their social stigma in a given school space. In the case of such groups, the teacher not only does not constitute a source of support or help, but becomes a factor directly causing or generating unwanted behaviour in others. In the light of Pierre Bourdieu's social theory, two processes determine the position of an individual within the social space. The first is the way in which a person has been placed in the social field by objective social forces on which they depend in said space. In the case of the school field, this primarily concerns the teachers. The second process is the positioning of the individual according to their personal autolocation potential. In the case of students with mild intellectual disabilities, their autolocation potential is low, so their place in school space is mainly determined by their teachers and, of course, their peers, which means that their

${ }^{16}$ M. Dudzikowa, Nauczyciel - uczeń, między przemoca a dialogiem: obszary napięć i interpretacji, Oficyna Wydawnicza „Impuls”, Kraków 1996.

17 J. Przewłocka, Bezpieczeństwo uczniów i klimat społeczny w polskich szkołach. Raport z badań, Wydawnictwo Instytutu Badań Edukacyjnych, Warsaw 2015, pp. 90-94; J. Maćkowicz, Nauczyciele wobec problemu dziecka krzywdzonego w rodzinie, Nowa Szkoła, 2005, no. 8, pp. 10-13; M. Zbroszczyk-Szczepaniak, Po pierwsze dziecko założenia programu irlandzkiego. III. Konferencja Naukowa „Standardy postępowania w zespole dziecka krzywdzonego", Warsaw, 02.12.2006, pp. 26-30. 
attitudes towards these children are particularly important for their adaptation and social integration. They can either foster their integration and normalisation, or exacerbate their isolation or aggression and violence perpetrated against them.

\section{Author's own research methodology}

The aim of the study was to determine whether and how often teachers' violent behaviour towards students with mild intellectual disabilities occur, and whether they are conditioned by the form of organisation of education, as well as whether there are differences in the experience of teacher violence between students with mild intellectual disabilities and those without any intellectual disabilities. The study covered 180 students with mild intellectual disabilities in fourth and fifth grades, 60 of whom attended special schools, 60 attended mainstream schools and 60 were taught in integrated classes. In order to eliminate factors reducing the reliability of the study, the following criteria were taken into account when selecting children for the test sample:

- a certificate confirming the need for special education on the grounds of mild intellectual disabilities (the certificate still uses the old, deprecated name: mild mental retardation);

- no additional disabilities - no occurrence of diagnosed motor, sensory or autism spectrum disorders;

- earlier education carried out in an educational organisation of the same kind;

- students of fourth and fifth grade in special schools, public schools or integration classes;

- students learning in the city (of more than 20,000 residents) in Greater Poland Voivodeship.

Due to the difficulties experienced while looking for children with mild intellectual disabilities attending public mainstream school, the author adopted a variable manner of selecting the sample. In the case of students attending special schools and an integrated classes, 
a stratified random sampling methodology was used, while in the case of students with mild intellectual disabilities attending a mainstream school, a targeted selection was carried out. The study also included students without intellectual disabilities attending classes with selected students with mild intellectual disabilities in mainstream schools and integrated classes. This was to verify whether the experience of aggression and violence perpetrated by teacher against students with mild intellectual disabilities in these two forms of educational organisation depends on the individual situation of the given student (related to the fact of having mild intellectual disabilities) or is consistent with the experiences of their ablebodied peers in the class. This group of respondents was selected with a targeted selection methodology, and in total 1164 students of public schools and 888 students of integration classes were covered by the study. The adopted research procedure was carried out by means of a diagnostic survey, in which a test was conducted on the basis of an IBE School Climate questionnaire on school aggression and violence, which after the pilot study was adapted to the needs and abilities of a student with mild intellectual disabilities. Different statistical methods were used in the study, depending on the assumed partial research objectives. The descriptive statistic measures such as: totals, averages, standard deviations and percentage fractions were used to characterise the studied group and variables. The significance of differences in the distribution of the number of the examined categorical variables was determined using $\chi^{2}$ (chi square) distribution. The calculations were made with IBM SPSS Statistics 25 software suite.

\section{Author's own research results}

The obtained results concerning the experience of students with mild intellectual disabilities in special, mainstream and integrated classes in the last four weeks before the study of violent behaviours perpetrated by teachers are presented in Table 1. 
Table 1. Teachers' aggressive and violent behaviours towards students with mild intellectual disabilities in three forms of education organisation

\begin{tabular}{|c|c|c|c|c|c|c|}
\hline \multirow{2}{*}{ Teacher yelled at you } & \multicolumn{2}{|c|}{ Special school } & \multicolumn{2}{|c|}{$\begin{array}{l}\text { Mainstream } \\
\text { school }\end{array}$} & \multicolumn{2}{|c|}{ Integration class } \\
\hline & $\mathrm{n}$ & $\%$ & $\mathrm{n}$ & $\%$ & $\mathrm{n}$ & $\%$ \\
\hline No & 38 & 63.33 & 23 & 38.33 & 30 & 50.00 \\
\hline Once & 19 & 31.66 & 11 & 18.33 & 18 & 30.00 \\
\hline 2-4 times & 2 & 3.33 & 21 & 35.00 & 6 & 10.00 \\
\hline More than 4 times & 1 & 1.66 & 5 & 8.33 & 6 & 10.00 \\
\hline \multirow{2}{*}{$\begin{array}{c}\text { Teacher said offensive } \\
\text { things to you }\end{array}$} & \multicolumn{2}{|c|}{ Special school } & \multicolumn{2}{|c|}{ General school } & \multicolumn{2}{|c|}{ Integration class } \\
\hline & $\mathrm{n}$ & $\%$ & $\mathrm{n}$ & $\%$ & $\mathrm{n}$ & $\%$ \\
\hline No & 58 & 96.66 & 45 & 75.00 & 52 & 86.66 \\
\hline Once & 1 & 1.66 & 12 & 20.00 & 6 & 10.00 \\
\hline $2-4$ times & 0 & 0.00 & 2 & 3.33 & 2 & 3.33 \\
\hline More than 4 times & 1 & 1.66 & 1 & 1.66 & 0 & 0.00 \\
\hline \multirow{2}{*}{$\begin{array}{l}\text { Teacher mocked, } \\
\text { ridiculed you in front } \\
\text { of other students }\end{array}$} & \multicolumn{2}{|c|}{ Special school } & \multicolumn{2}{|c|}{ General school } & \multicolumn{2}{|c|}{ Integration class } \\
\hline & $\mathrm{n}$ & $\%$ & $\mathrm{n}$ & $\%$ & $\mathrm{n}$ & $\%$ \\
\hline No & 55 & 91.66 & 26 & 43.33 & 44 & 73.33 \\
\hline Once & 3 & 5.00 & 18 & 30.00 & 12 & 20.00 \\
\hline $2-4$ times & 1 & 1.66 & 13 & 21.66 & 4 & 6.66 \\
\hline More than 4 times & 1 & 1.66 & 3 & 5.00 & 0 & 0.00 \\
\hline \multirow{2}{*}{$\begin{array}{c}\text { Teacher hit or jerked } \\
\text { you }\end{array}$} & \multicolumn{2}{|c|}{ Special school } & \multicolumn{2}{|c|}{ Mainstream school } & \multicolumn{2}{|c|}{ Integration class } \\
\hline & $\mathrm{n}$ & $\%$ & $\mathrm{n}$ & $\%$ & $\mathrm{n}$ & $\%$ \\
\hline No & 59 & 98.33 & 57 & 95.00 & 56 & 93.33 \\
\hline Once & 0 & 0.00 & 2 & 3.33 & 4 & 6.66 \\
\hline 2-4 times & 0 & 0.00 & 1 & 1.66 & 0 & 0.00 \\
\hline More than 4 times & 1 & 1.66 & 0 & 0.00 & 0 & 0.00 \\
\hline
\end{tabular}

Source: Author's own compilation based on study results.

The conducted analyses lead to the conclusion that the observed differences in teachers' violent behaviour towards students with mild intellectual disabilities are statistically significant, while taking 
into consideration the form of education, in the following forms: shouting at students $\left(\chi^{2}(6)=30.35 ; \mathrm{p}<0.001\right)$, using offensive words $\left(\chi^{2}(6)=14.22 ; p=0.02\right)$, mockery, ridiculing in front of other students $\left(X^{2}(6)=37.15 ; p<0.001\right)$. All these aggressive behaviour perpetrated by teachers was most often experienced by students with mild intellectual disabilities from mainstream schools, a little less frequently by students from integrated classes and the least frequently by students attending special schools. There were no statistically significant differences between students with mild intellectual disabilities from the three forms of education in the experience of being struck or jerked by the teacher $\left(x^{2}(6)=8.081 ; p=0.232\right)$. Such behaviour was rarely seen in all types of schools.

It is worth noting that a statistically significant difference between students with mild intellectual disabilities and their ablebodied classmates was also revealed in the mainstream schools, with regards to experiencing violent behaviours perpetrated by teachers (shouting at students $\left(\chi^{2}(3)=25.49\right.$; $p<0.001$ ), using offensive words $\left(\chi^{2}(3)=17.71 ; p=0.02\right)$, mocking, ridiculing in front of other students $\left.\left(\chi^{2}(3)=74.93 ; p<0.001\right)\right)$. Able-bodied students experienced such behaviour much less often than their peers with mild intellectual disabilities. Students in mainstream schools revealed that they never experienced being yelled at by teacher $(46.7 \%)$, they never had offensive words used against them $(90.8 \%)$, and that they were never mocked or ridiculed in front of other students $(82.6 \%)$, while for students with mild intellectual disabilities it was $38.3 \%, 75 \%$ and $43.3 \%$, respectively. The differences between students with mild intellectual disabilities and their able-bodied peers in integrated classes were not statistically significant, although they also revealed more frequent experience of violent behaviours perpetrated by the teacher by students with mild intellectual disabilities. The results reveal that teachers in mainstream schools perpetrate violent behaviour against students with mild intellectual disabilities with the highest frequency. Such behaviour by teachers may be indicative of a low level of preparation for work with students with mild intellectual disabilities, and therefore a lack of understanding of their behaviour and needs. 
One of the consequences of the frequency of the use of violent behaviours against students with mild intellectual disabilities in the three forms of organisation of education is that students declare the number of teachers they fear and like. The results obtained in this area revealed statistically significant differences in terms of the form of education both in the number of teachers whom students are afraid of $\left(\chi^{2}(14)=26.81 ; p=0.02\right)$ and the number of teachers whom they like $\left(\chi^{2}(46)=65.07 ; p=0.033\right)$. Students attending special schools most often declared that there were no teachers they were afraid of $(83.3 \%)$, in the case of integration classes it amounted to $70 \%$, and in the case of mainstream schools it was only $56.7 \%$. In the case of mainstream schools and integrated classes, there were students who revealed that they were afraid of up to seven teachers, while in the case of students with mild intellectual disabilities attending special schools one person indicated three such teachers, the remaining students indicated one or two. The inverse proportion between the students taking advantage of these three forms of education was revealed in the number of teachers they like. None of the students from special schools indicated that there are no teachers whom they like, while $21.7 \%$ of students from integration classes and $15 \%$ of students attending mainstream schools gave that response. The majority of special school students indicated a higher number of teachers they like (with 48 teachers indicated as the maximum value), while students from mainstream schools and integration classes mainly indicated one or two such teachers.

The specific situation of students with mild intellectual disabilities in mainstream schools and integrated classes was confirmed by the results of analyses comparing students with mild intellectual disabilities and their able-bodied peers. The results revealed statistically significant differences between students with mild intellectual disabilities and their able-bodied peers in the declared number of teachers of whom they are afraid of, both in mainstream schools $\left(x^{2}(7)=205.9 ; p<0.001\right)$ and integrated classes $\left(x^{2}(6)=134.9\right.$; $\mathrm{p}<0.001)$. Able-bodied students attending mainstream schools and integrated classes declare that they are less afraid of their teachers 
than their peers with mild intellectual disabilities. The results concerning the number of teachers whom their students like turned out to be statistically significant due to the absence or presence of mild intellectual disabilities in mainstream schools $\left(X^{2}(11)=173 ; p<0.001\right)$ and integrated classes $\left(\chi^{2}(13)=207.8 ; p<0.001\right)$. Able-bodied students usually indicate that they like at least 2 (about $30 \%$ of students from mainstream schools and integrated classes), 3 (about $30 \%$ of students from mainstream schools and integrated classes) or 4 teachers (about $15 \%$ of students from mainstream schools and integrated classes). The lack of such teachers was indicated by only $0.2 \%$ of students from mainstream schools and $0.6 \%$ of students attending integrated classes, while $21.7 \%$ of students with mild intellectual disabilities attending integrated classes and $15 \%$ of students with mild intellectual disabilities from mainstream schools indicated such a lack.

\section{Conclusion}

Summing up the results obtained in the area of teachers' violent behaviour towards students with mild intellectual disabilities in the three forms of education shows that students from mainstream schools and integrated classes experience such behaviour perpetrated by teachers much more often than students from special schools; however, students with mild intellectual disabilities in integrated classes experience such behaviours less often than students from mainstream schools. Students with mild intellectual disabilities from mainstream schools and integrated classes also experience more victimisation by teachers than their able-bodied peers. Experiencing violent behaviour perpetrated by teachers goes hand in hand with the higher declared number of teachers whom students are afraid of and a lower number of teachers whom they like. The results of the study indicate that students with mild intellectual disabilities in mainstream schools and integrated classes are in a significantly worse position when it comes to experiencing aggression and vio- 
lence perpetrated by their teachers than their peers with mild intellectual disabilities attending special schools and their able-bodied peers. The fact that such behaviours perpetrated by teachers is not experienced with the same frequency by special school students and able-bodied students confirms the low level of preparation of teachers, mainly from mainstream schools, to working with students with mild intellectual disabilities, presented in numerous studies ${ }^{18}$, which indicates that despite years, unfortunately little has changed in this area.

The lack of adequate preparation of teachers from mainstream schools and integrated classes to working with students with mild intellectual disabilities in the context of the analysed experience of school aggression and violence by these students is particularly worrying. Teachers should not only be able to adapt the work to the abilities and needs of a student with mild intellectual disabilities, but above all, they should instil in them a sense of security and acceptance; however, not only do they fail at this task, but also they become perpetrators of violence. A teacher who perpetrates aggressive behaviours towards students with mild intellectual disabilities destroys the sense of security among such students, when they experience violence, and they lose the person they can turn to for help in such a difficult situation. Secondly, such a teacher models the behaviour of other students who, either by imitating the teacher or

18 See for example: M. Buchnat, Kompetencje i oczekiwania nauczyciela do pracy $z$ dzieckiem ze specjalnymi potrzebami edukacyjnymi w nowej szkolnej rzeczywistości, Studia Edukacyjne, 2014, no. 31, pp. 177-195; M. Chodkowska, Z. Kazanowski, Socjopedagogiczne konteksty postaw nauczycieli wobec edukacji inkluzyjnej, Wyd. UMCS, Lublin 2007; B. Jachimczak, Gotowość nauczycieli szkół ogólnodostępnych do pracy z uczniem o specjalnych potrzebach edukacyjnych, [in:] Miejsce Innego we wspótczesnych naukach o wychowaniu - wyzwania praktyki, I. Chrzanowska, B. Jachimczak (eds.), Satori, Łódź 2008, pp. 136-145; Z. Gajdzica, Opinie nauczycieli szkół ogólnodostępnych na temat edukacji wtączającej uczniów z lekkim upośledzeniem umysłowym w kontekście toczacej się reformy kształcenia specjalnego, [in:] Uczeń z niepetnosprawnościa w szkole ogólnodostępnej, Z. Gajdzica (ed.), Humanitas, Sosnowiec 2011, pp. 56-82; S. Sadowska, Jakość życia uczniów z niepetnosprawnościa intelektualną w stopniu lekkim. Oficyna Wydawnicza „Impuls”, Kraków 2006. 
feeling that their behaviour is not negated, also perpetrate violence against students with mild intellectual disabilities. The study carried out by Jadwiga Przewłocka ${ }^{19}$ revealed that the issue of peer violence is less prominent in schools where teachers are interested in their students and where they are perceived by children and youth as friendly and more willing to help. It is also important to remember that conflict with a teacher is treated as a source of severe stress, while mental abuse, mockery or labelling students often leads to feelings of anger, frustration and, consequently, aggression, which can be directed at students and teachers alike. Therefore, it seems important to pay particular attention to preparing teachers for working with students with mild intellectual disabilities, aimed not only at raising the level of education of students with mild intellectual disabilities in forms of non-segregated education, but above all at eliminating teachers' aggressive behaviours towards this group of students.

\section{References}

Brzezińska A., Jak rodzi się agresja?, [in:] Dzieci i młodzież wobec agresji i przemocy, A. Brzezińska, E. Hornowska (eds.), Wydawnictwo Naukowe Scholar, Warsaw 2004, pp. 107-126.

Buchnat M., Kompetencje i oczekiwania nauczyciela do pracy $z$ dzieckiem ze specjalnymi potrzebami edukacyjnymi w nowej szkolnej rzeczywistości, Studia Edukacyjne, 2014, no. 31, pp. 177-195.

Buchnat M., Percepcja klimatu szkoty przez uczniów z lekka niepetnosprawnością intelektualna w trzech formach kształcenia a agresja i przemoc szkolna, Wydawnictwo Naukowe UAM, Poznań 2019.

Chmura-Rutkowska I., Przemoc rówieśnicza w gimnazjum a płeć. Kontekst społecznokulturowy, „Forum Oświatowe”, 2012, no. 46(1), pp. 41-73.

Chodkowska M., Kazanowski Z., Socjopedagogiczne konteksty postaw nauczycieli wobec edukacji inkluzyjnej. Wyd. UMCS, Lublin 2007.

Czub M., Zachowanie agresywne - agresja - osiaganie. Analiza zjawiska agresji jako istotnego czynnika w procesie socjalizacji, Kwartalnik Pedagogiczny, 1992, no. 1, pp. 126-135.

${ }^{19}$ J. Przewłocka, Bezpieczeństwo uczniów i klimat społeczny w polskich szkołach. Raport z badań, Wydawnictwo Instytutu Badań Edukacyjnych, Warsaw 2015. 
Dudzikowa M., Nauczyciel - uczeń, między przemoca a dialogiem: obszary napięć $i$ interpretacji, Oficyna Wydawnicza „Impuls”, 1996.

Frączek A., Agresja i przemoc wśród dzieci i młodzieży jako zjawisko społeczne, [in:] Agresja wśród dzieci i młodzieży. Perspektywa psychoedukacyjna, A. Frączek, I. Pufal-Struzik (eds.), Wydawnictwo Pedagogiczne ZNP, Kielce 1996.

Frączek A., Czynności agresywne jako przedmiot studiów eksperymentalnej psychologii społecznej, [in:] Studia nad psychologicznymi mechanizmami czynności agresywnych, ed. A. Frączek, Zakład Narodowy im. Ossolińskich - Wydawnictwo PAN, Wrocław-Warsaw-Kraków-Gdańsk 1979, pp. 9-32.

Gajdzica Z., Opinie nauczycieli szkót ogólnodostępnych na temat edukacji włączającej uczniów z lekkim upośledzeniem umysłowym w kontekście toczacej się reformy ksztatcenia specjalnego, [in:] Uczeń z niepetnosprawnościa w szkole ogólnodostępnej, Z. Gajdzica (eds.), Humanitas, Sosnowiec 2011, pp. 56-82.

Hodges E., Perry D., Personal and interpersonal antecedents and consequences of victimization by peers, Journal of Personality and Social Psychology, 1999, no. 76(4), pp. 677-685.

Jachimczak B., Gotowość nauczycieli szkót ogólnodostępnych do pracy z uczniem o specjalnych potrzebach edukacyjnych, [in:] Miejsce Innego we współczesnych naukach o wychowaniu - wyzwania praktyki, I. Chrzanowska, B. Jachimczak, Satori, Łódź 2008. pp. 136-145.

Komendant-Brodowska A., Agresja i przemoc szkolna. Raport o stanie badań, Wydawnictwo Instytutu Badań Edukacyjnych, Warsaw 2014.

Komendant-Brodowska A., Baczko-Dombi A., Giza-Poleszczuk A. (eds.), Przemoc w szkole. Raport z badań. Warsaw 2011. szkolabezprzemocy.pl. [retrieved on: 28.11.2019].

Kulesza M., Klimat szkoty a zachowania agresywne i przemocowe uczniów, Wydawnictwo Uniwersytetu Łódzkiego, Łódź 2011.

Maćkowicz J., Nauczyciele wobec problemu dziecka krzywdzonego w rodzinie, Nowa Szkoła, 2005, no. 8, pp. 10-13.

Meier U., Aggressionen und Gewalt in der Schule. Zur Dialektik von Schülerpersönlichkeiten, Lernumwelten und schulischem Sozialklima. Jugendsoziologie, vol. 6, Münster 2004.

Mikrut A., Stygmat 'upośledzenie umystowe' a ryzyko zastania ofiara przemocy, Szkoła Specjalna, 2007, no. 3, p. 184-191.

Murphy W.J., The victim advocacy and research group: Serving a growing need to provide rape victims with personal legal representation to protect privacy rights and to fi ght gender bias in the criminal justice", Journal of Social Distress and the Homeless, 2001, 10, pp. 123-138.

Olweus D., Mobbing. Fala przemocy w szkole. Jak ja powstrzymać?, Agencja Wydawnicza Jacek Santorski \& Co, Warsaw 2007.

Ostrowska K., Surzykiewicz J., Zachowania agresywne w szkole. Badania porównawcze 1997 i 2003, Centrum Metodyczne Pomocy Psychologiczno-Pedagogicznej, Warsaw 2005. 
Pufal-Struzik I. (ed.), Agresja dzieci i młodzieży, Wydawnictwo Pedagogiczne ZNP, Kielce 2007.

Perry D.G., Kusel S.J., Perry L.C. (1998), Victims of peer aggression, Developmental Psychology, 1998, no. 24(6), pp. 807-814.

Plichta P. (2015), Dzieci i młodzież z niepetnosprawnością intelektualna a narażenie na agresje rówieśnicza, [in:] Przemoc rówieśnicza wobec dzieci ze SPE. Materiały pokonferencyjne, Wydawnictwo Instytutu Badań Edukacyjnych, Warsaw 2014, pp. 35-42.

Poraj G., Szkoła wobec agresji, Psychologia w Szkole, 2006, no. 1, pp. 3-24.

Pospiszyl I., Ofiary chroniczne. Przypadek czy konieczność, Wydawnictwo APS, Warsaw 2003.

Przewłocka J., Bezpieczeństwo uczniów i klimat społeczny w polskich szkołach. Raport z badan, Wydawnictwo Instytutu Badań Edukacyjnych, Warsaw 2015.

Pyżalski J., Przemoc rówieśnicza w szkole - badania retrospektywne studentów pedagogiki, Studia Edukacyjne, 2015, no. 34, pp. 177-196.

Sadowska S., Jakość życia uczniów z niepetnosprawnościa intelektualną w stopniu lekkim. Oficyna Wydawnicza "Impuls", Krakow 2006.

Schwartz D., Dodge K.A., Coie J.D. The emergence of chronic peer victimization in boys' play groups, Child Development, 1993, 64(6), pp. 1755-1772.

Surzykiewicz J., Agresja i przemoc w szkole. Uwarunkowania socjoekologiczne, Centrum Metodyczne Pomocy Psychologiczno-Pedagogicznej, Warsaw 2000.

Sveinsson A.V., Morris R.J., School bullying and victimization of children with disabilities, [in:] Disability Research and Policy: Current Perspectives, ed. R.J. Morris, Routlege, London 2005.

Włodarczyk J., Makaruk K., Ogólnopolska diagnoza problemu przemocy wobec dzieci. Wyniki badania, Fundacja Dzieci Niczyje, Warsaw 2013.

Włodarczyk J., Przemoc rówieśnicza. Wyniki Ogólnopolskiej diagnozy problemu przemocy wobec dzieci, [in:] Dziecko krzywdzone. Teoria, badania, praktyka, 2013, 12(3), pp. 63-81.

Zbroszczyk-Szczepaniak M., Po pierwsze dziecko - założenia programu irlandzkiego. III Konferencja Naukowa „Standardy postępowania w zespole dziecka krzywdzonego", Warsaw 02.12.2006, pp. 26-30. 